\title{
Why one species in New Zealand, Pugetia delicatissima (Kallymeniaceae, Rhodophyta), should become two new genera, Judithia gen. nov. and Wendya gen. nov.
}

\author{
ROBERTA D'ARCHINO ${ }^{1}$, SHOWE-MEI LIN ${ }^{2}$, PAUL W. GABRIELSON ${ }^{3}$ AND \\ GIUSEPPE C. ZUCCARELLO ${ }^{4}$
}

${ }^{1}$ National Institute of Water and Atmospheric Research Ltd, Private Bag 14-901, Wellington 6241, New Zealand

${ }^{2}$ Institute of Marine Biology, National Taiwan Ocean University, Keelung 20224, Taiwan, Republic of China

${ }^{3}$ Herbarium and Biology Department, University of North Carolina-Chapel Hill, Coker Hall, CB 3280, Chapel Hill, North Carolina 27599-3280, USA

${ }^{4}$ School of Biological Sciences, Victoria University of Wellington, PO Box 600, Wellington, New Zealand

(Received 22 April 2015; revised 10 July 2015; accepted 19 July 2015)

\begin{abstract}
Blade-forming red algae occur worldwide and, prior to DNA sequencing, had been notoriously difficult to identify and classify, especially when lacking critical reproductive features. This, coupled in New Zealand with many longstanding assumptions that taxa were identical to non-New Zealand species or genera, resulted in many misapplied names. Pugetia delicatissima R.E. Norris, an endemic New Zealand blade-forming species of the family Kallymeniaceae, is actually comprised of one existing and one new species belonging to two distinct genera, as established by our phylogenetic analyses of DNA sequences from the $r b c \mathrm{~L}$ gene. Analyses of combined $r b c \mathrm{~L}$ and LSU genes showed that neither is closely related to the generitype of Pugetia, the northern-eastern Pacific, $P$. fragilissima Kylin. We propose the names Judithia and Wendya for these two newly revealed genera. In addition to diagnostic $r b c \mathrm{~L}$ and LSU sequences, Judithia is morphologically and anatomically characterized by rounded to oblong blades that do not taper basally at the stipe, loosely aggregated surface cortical cells and cystocarps lacking both a pericarp and an ostiole, all features observed in the holotype of $P$. delicatissima. Wendya, in contrast, is characterized by blades that taper both apically and basally, compactly arranged surface cortical cells and cystocarps that have both a pericarp and a distinct ostiole. The two genera also are distinguished from one other, as well as from Pugetia by features of pre- and post-fertilization development, including the number of subsidiary cells produced on carpogonial and auxiliary branch systems, whether subsidiary cells in the carpogonial branch system fuse with the supporting cell or not, and the site of origin of gonimoblast cells. Although small in area, New Zealand hosts ten of the 27 currently recognized genera in the Kallymeniaceae and is the southern-hemisphere region of greatest generic diversification in this family.
\end{abstract}

Key words: DNA sequencing, endemic genera, large-subunit ribosomal RNA (LSU), molecular phylogeny, post-fertilization development, $r b c \mathrm{~L}$, systematics

\section{INTRODUCTION}

New Zealand hosts a very diverse marine macroalgal flora (Nelson, 2012), one that contains many species of foliose red algae. Recent detailed studies of these red algal blades have uncovered unexpected diversity that has led to descriptions of new genera and species that previously were misidentified or assigned longstanding names based on taxa from extra-New Zealand floras (Kraft 1976; Hommersand et al., 2010; D'Archino et al., 2010, 2012, 2014; Nelson et al., 2011; Lin et al., 2012b).

Correspondence to: Roberta D'Archino.

E-mail: roberta.darchino@niwa.co.nz; Showe-Mei Lin. E-mail: linsm@ntou.edu.tw

This article was originally published with errors. This version has been corrected. Please see Corrigendum (http://dx.doi.org/10.1080/ 09670262.2015.1135657).
The family Kallymeniaceae of the order Gigartinales, contains 27 genera (Guiry \& Guiry, 2015) and is especially diverse in temperate regions of both hemispheres. Several new genera recently have been described from Antarctica, New Zealand, Chile and Canada (Hommersand et al., 2009; D’Archino et al., 2010, 2012; Clarkston \& Saunders, 2012). Currently, nine genera and 18 species of Kallymeniaceae are reported from New Zealand (Dalen \& Nelson, 2013), marking it as a region with one of the most diverse concentrations of this family in the world and made even more so by the number of poorly defined and undescribed members still awaiting valid names. Adams et al. (1974) noted the presence of one or more undescribed species of Kallymenia J. Agardh, and D'Archino et al. (2011) included five undescribed 
New Zealand Kallymeniaceae on the basis of DNA-sequence analysis, formally designating one as Ectophora marginata D'Archino \& W.A. Nelson but leaving the remaining four undescribed for lack of adequate material. In this paper we focus on specimens conforming to Pugetia delicatissima (Norris 1957), a species that was not in the same clade as the generitype, $P$. fragilissima, from the Salish Sea of Washington, USA (D'Archino et al. 2011; Lin et al. 2012a).

Pugetia delicatissima was described based on material collected from drift in 1933 by Robert Laing at Gore Bay on the east coast of the South Island (Norris, 1957). The two main features suggesting to Norris (1957, p. 275) that this species should be included in Pugetia Kylin were the medulla, mainly composed of large, rounded cells rather than mostly of filaments, and the presence of monocarpogonial supporting cells. Apart from its type locality, P. delicatissima had also been reported from the North Island side of Cook Strait, several sites on the South Island, Stewart I., Chatham Is., and the subantarctic Antipodes and Auckland Islands (Adams, 1994).

Specimens in WELT and AK (Thiers, 2015) that conformed to $P$. delicatissima display great morphological variation. Whether this reflected one highly polymorphic species or several cryptic species, each less morphologically diverse, had long vexed taxonomists. Herein, herbarium and newly collected specimens identified as $P$. delicatissima, from numerous locations and displaying a broad range of morphologies, were re-examined in light of DNA sequence data. We found that what superficially appeared to be a single variable species comprises two non-sister lineages that we describe below as two new genera.

\section{MATERIALS AND METHODS}

Collections were made mainly by scuba diving to $20 \mathrm{~m}$ depths on the Otago Peninsula, South Island (December 2008, January 2010), Stewart Island (March 2009, November 2011) and on the North Island at Castle Point (November 2010, August 2014), and Wellington (October 2014). Specimens for morphological observations were pressed on herbarium sheets and fertile material was preserved in 3-5\% formalin seawater. Subsamples for DNA sequencing were desiccated in silica gel. Voucher specimens have been deposited in WELT. Hand sections were stained with $1 \%$ aniline blue acidified and mounted in 50\% Karo ${ }^{\circledR}$ syrup (Englewood Cliffs, New Jersey, USA). To highlight nuclei, sections were stained with Wittmann's aceto-iron-haematoxylin-chloral hydrate (Wittmann, 1965), mounted in 50\% Hoyer's mounting medium (Lin et al., 2004) or placed in an alcohol/xylene series after staining and mounted in Piccolyte (Wards Natural Science Establishment, Inc., Rochester, New York, USA) (Lin et al., 2001). Photomicrographs were taken on an Olympus BX51 microscope with a Q-imaging digital camera (Burnaby, BC, Canada) or with an Olympus BX53 (Tokyo, Japan) with a SC100 (Münster, Germany) digital camera.
Photos of vouchers were taken with a digital camera Canon G12 (Japan). Herbarium specimens referred to P. delicatissima and unidentified specimens of bladed red algae in WELT and AK were also examined anatomically.

\section{DNA sequencing and analyses}

DNA was extracted with a modified CTAB protocol (Zuccarello \& Lokhorst, 2005), with the Hughey protocol (Hughey et al. 2001) or using the DNeasy Plant Mini Kit (Qiagen, Valencia, California, USA) following the manufacturer's instructions. The plastid-encoded large subunit of the ribulose bisphosphate carboxylase/oxygenase gene $(r b c \mathrm{~L})$, was amplified using the primer combination F57-R753 and F753-RrbcS (Freshwater \& Rueness, 1994). PCR conditions consisted of an initial denaturation of $4 \mathrm{~min}$ at $94^{\circ} \mathrm{C}$, followed by 37 cycles of $1 \mathrm{~min}$ at $94^{\circ} \mathrm{C}, 1 \mathrm{~min}$ at $45^{\circ} \mathrm{C}$ and $1 \mathrm{~min}$ at $72^{\circ}$ $\mathrm{C}$, with a final $5 \mathrm{~min}$ extension at $72^{\circ} \mathrm{C}$. The nuclear-encoded nuclear large subunit of ribosomal RNA (LSU) was amplified using primers from Harper \& Saunders (2001) following Zuccarello \& West (2002). PCR products were cleaned using ExoSAP-IT reagent (USB, Cleveland, Ohio, USA) and commercially sequenced (Macrogen Inc., Seoul, Korea). Sequences were edited, assembled and aligned using the Geneious software package (Biomatters, available from http://www.geneious.com/). Alignments for $r b c \mathrm{~L}$ were straightforward, no gaps were found in the dataset. The LSU data was aligned using MAFFT alignment software (Katoh et al., 2002) in the Geneious program and modified by eye.

jMODELTEST 2.1.1 (Guindon \& Gascuel, 2003; Darriba et al., 2012) was used to find the model of sequence evolution that best fit the dataset under Akaike Information Criterion (AIC). Maximum likelihood (ML) analysis was performed with RAxML 7.2.8 (Stamatakis, 2006) with all three codon positions partitioned and the GTR+gamma model and 500 non-parametric bootstrap replicates (Felsenstein, 1985). For the combined LSU and $r b c \mathrm{~L}$ dataset four partitions were used also using the GTR model. Bayesian inference was performed with MrBayes v3.1.2 (Ronquist \& Huelsenbeck, 2003). All codons and genes were partitioned separately. Analyses consisted of two independent simultaneous runs of one cold and three incrementally heated chains, and $3 \times 10^{6}$ generations with sampling every 1000 generations. Log files of the runs were checked with Tracer v1.4.1 (Rambaut \& Drummond, 2007) and a burn-in sample of 300 trees was removed before calculating the majority-rule consensus tree. For the $r b c \mathrm{~L}$ dataset, Gigartina pistillata (S.G. Gmelin) Stackhouse and Sphaerococcus coronopifolius Stackhouse were used as outgroups. For the combined dataset Dilsea californica (J. Agardh) Kuntze and D. natashe (S.C. Lindstrom) G.W. Saunders \& S.C. Lindstrom were used as outgroups. See Table S1 in the supplementary material for a list of samples sequenced. The $r b c \mathrm{~L}$ dataset included sequences for the recently described, monotypic, Antarctic genera Leniea R.L. Moe and Austropugetia R.L. Moe (GenBank accession numbers KR231933 and KR231934, respectively) but LSU sequences were not obtained for these taxa.

Sequences of $P$. fragilissima from the type locality, Canoe Island (GenBank accession numbers KR231931) and Callophyllys crispata Okamura, from Japan (GenBank accession numbers KR231932, KR231920) were newly generated. 


\section{RESULTS}

The $r b c \mathrm{~L}$ dataset consisted of 53 taxa each of 1266 base pairs (bp), including 49 species in 19 genera belonging to the Kallymeniaceae (Fig. 1). Samples anatomically referable to $P$. delicatissima fell into two distinct clades both distant from the clade that contains the generitype, $P$. fragilissima. The new genus Judithia is proposed (see below) to accommodate the specimens most closely conforming to the description of $P$. delicatissima by Norris (1957). This clade is closely related to New Zealand specimens called 'Callophyllis' variegata (Bory de SaintVincent) Kützing, but this entity is far from its Chilean type locality, displays some discordant anatomical features, and requires further study. Specimens that also were referred to $P$. delicatissima but that display a suite of differing habit and anatomical features were found in yet another clade, and we propose the new genus, Wendya, to accommodate them. Wendya is in a moderately supported clade (ML BP 62, BI 1.0) containing the generitype, Callophyllis variegata from Chile, as well as several other species of Callophyllis Kützing. It is sister to these species, albeit without strong support (ML BP 58, BI 0.78, not shown). Many of the terminal clades have moderate support whereas several of the internal nodes remain poorly supported (Fig. 1).

The combined $r b c \mathrm{~L}$ and LSU analyses included 27 taxa of $3923 \mathrm{bp}$ each representing 16 genera of the Kallymeniaceae plus two outgroup genera from Dumontiaceae (Fig. 2), the family shown by Saunders et al. (2004) to be sister to Kallymeniaceae. The two newly proposed genera are distinct from one another, and did not group with $P$. fragilissima. Judithia once again grouped with samples currently named 'Callophyllis' variegata from New Zealand, whereas Wendya was again sister to the clade that included the generitype of Callophyllis, but this time with strong support (ML BP 93, BI 1.0).

\section{Judithia D'Archino \& S.-M. Lin gen. nov.}

Description: Thalli erect, foliose, arising abruptly from a $<1 \mathrm{~mm}$ stipe attached to the substratum by a small basal disc. Blades initially ovoid, becoming elongated, one or more times divided, usually exhibiting rounded lobes. Cortex composed of a single loosely aggregated surface layer of small cells, these subtended by a single layer of angular, uncompacted cells that border one or two layers of large ovoid hyaline medullary cells interspersed with small-celled filaments. Tetrasporangia cruciate, scattered in the outer cortex. Gametophytes apparently dioecious; female gametophytes and tetrasporophytes isomorphic. Carpogonial branch system non-procarpic and monocarpogonial, each bearing three multinucleate subsidiary cells and one threecelled carpogonial branch. Auxiliary cells bearing three or four subsidiary cells, each subsidiary cell occasionally divided transversely once or twice. Subsidiary cells on supporting cells enlarging and becoming lobed following presumed fertilization and remaining distinct during cystocarp development, each cutting off small cells that give rise to short filaments connecting with modified, darkly stained subcortical or medullary cells and presumably depositing zygote nuclei, these cells in turn producing additional short filaments that diploidize subsidiary cells of the auxiliary-cell system but not fusing with the auxiliary cell itself. Gonimoblast filaments arising from subsidiary cells. Carposporangia developing in clusters and surrounded by sterile gonimoblast filaments. Pericarps lacking or very rudimentary, non-ostiolate. Spermatangia not observed.

TYPE SPECIES: Judithia delicatissima (R.E. Norris) D'Archino \& S.-M. Lin comb. nov.

ETYMOLOGY: Named in honour of Dr Judith Sutherland for her contributions to the New Zealand marine flora.

Judithia delicatissima (R.E. Norris) D'Archino \& S.-M. Lin comb. nov.(Figs 3-29)

Basionym: Pugetia delicatissima R.E. Norris 1957 (Morphological studies of the Kallymeniaceae. University of California Press, p. 273, fig. 6 B-J, pl. 31).

Holotype: UC 513609 (Fig. 3), collected by Robert M. Laing (n. 2443), Gore Bay, December 1933. Pl. 31 (Norris, 1957).

Type locality: Gore Bay, Canterbury, New Zealand, drift. Growing on Epymenia Kützing.

Specimens examined:

South Island: Marfell's Beach, South Island $\left(41^{\circ}\right.$ 43.67' S, $174^{\circ} 13.01^{\prime}$ E), 7 December 2005, $W$. Nelson\& K. Neill, drift, WELT A024374; Marfell's Beach, 25 October 2010, R. D'Archino\& W.A. Nelson, drift, WELT A033080- A033082; Karitane Beach, Dunedin $\left(45^{\circ} 64.13^{\prime} \mathrm{S}, 170^{\circ} 66.93^{\prime} \mathrm{E}\right), 11$ December 2008, R. D'Archino, 5-10 m, WELT A024372; Railway Bridge, Otago Harbour $\left(45^{\circ}\right.$ $\left.50.09^{\prime} \mathrm{S}, 170^{\circ} 35.21^{\prime} \mathrm{E}\right), 4$ January $2011, R$. D'Archino, on piles $1 \mathrm{~m}$ depth, WELT A033083A033084; Portobello, Otago Harbour, 22 October 1953, E.J. Batham on Piura stalk, WELT A009402; Oamaru, 11 October 1988 C.H. Hay - growing on bryozoan on a wharf pile, WELT A018994; Oamaru, 2 October 1989, C.H. Hay WELT A024374, WELT A019673; Stewart Island: Halfmoon Bay, 30 October 2004, M.H. Hommersand \& D.W. Freshwater, NCU 634646; Mill Creek Estuary, HM587166, HM587234, 31 October 2004, M.H. Hommersand \& D.W. Freshwater, NCU 634639; The Neck, 19 


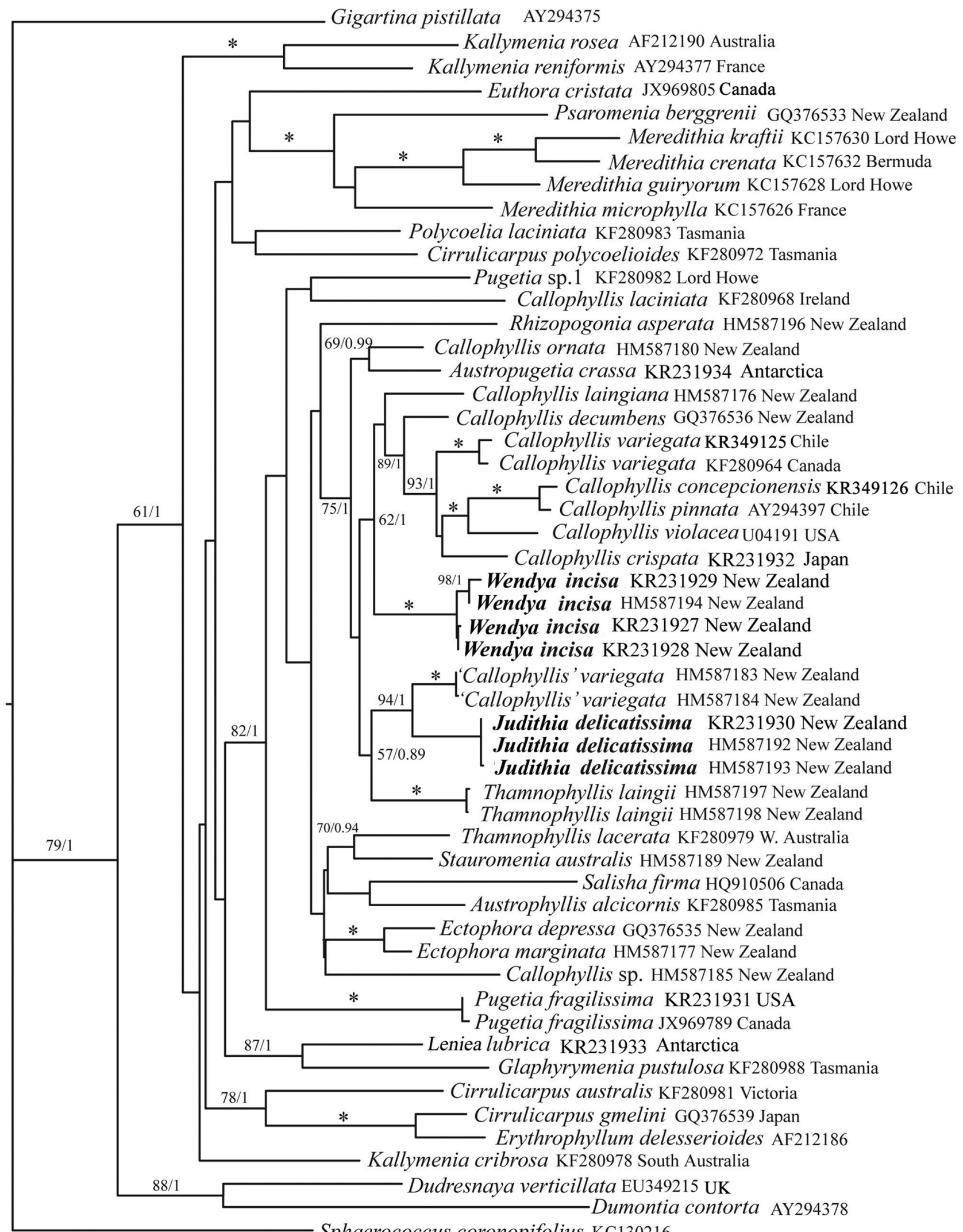

Sphaerococcus coronopifolius KC130216

0.03

Fig. 1. ML topology of analysed $r b c \mathrm{~L}$ gene sequences of select Kallymeniaceae and outgroup taxa. * $=\geq 95 \%$ ML bootstrap values (ML BP) and $\geq 0.95$ Bayesian posterior probabilities (BI). Other values associated with branches = RAxML bootstrap percentage/ Bayesian posterior probabilities. 


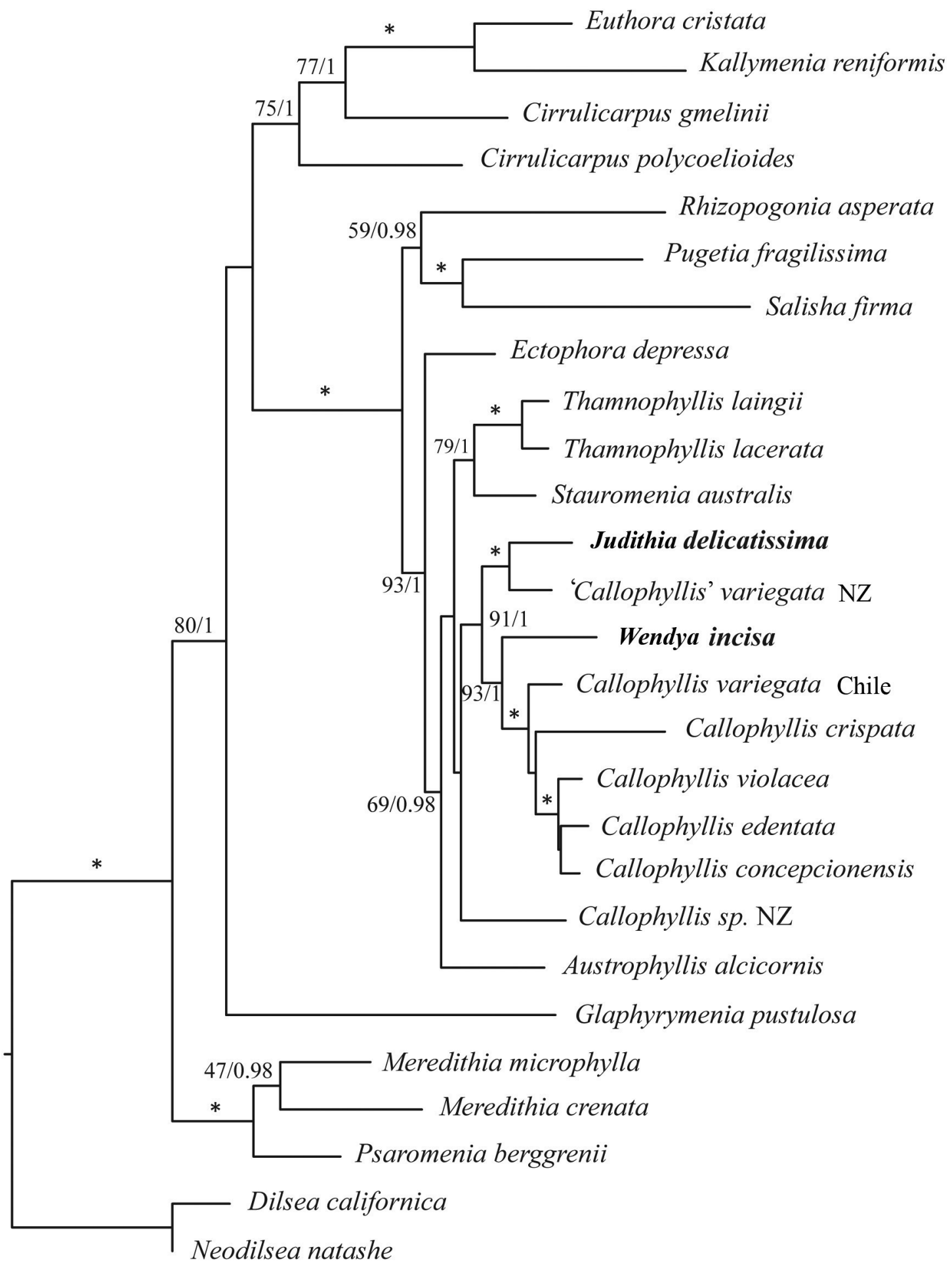

0.03

Fig. 2. Combined analysis of $r b c \mathrm{~L}$ and LSU of select Kallymeniaceae and outgroup taxa. $*=\geq 95 \%$ ML bootstrap values (ML BP) and $\geq 0.95$ Bayesian posterior probabilities $(\mathrm{BI})$. Other values associated with branches $=$ RAxML bootstrap percentage/Bayesian posterior probabilities.

October 2001, W. Nelson \& T. Farr, WELT A026290; Halfmoon Bay, 27 January 1983, N. Adams, dredge, 8-12 m, WELT A013549; Ulva I., 29 January 1983, C.H. Hay, WELT A013551.
Habitat and seasonality: On exposed or sheltered coasts from low intertidal to $20 \mathrm{~m}$ depths, mostly epiphytic, occasionally epizoic or epilithic; collections all from early spring or summer, possibly seasonal. 

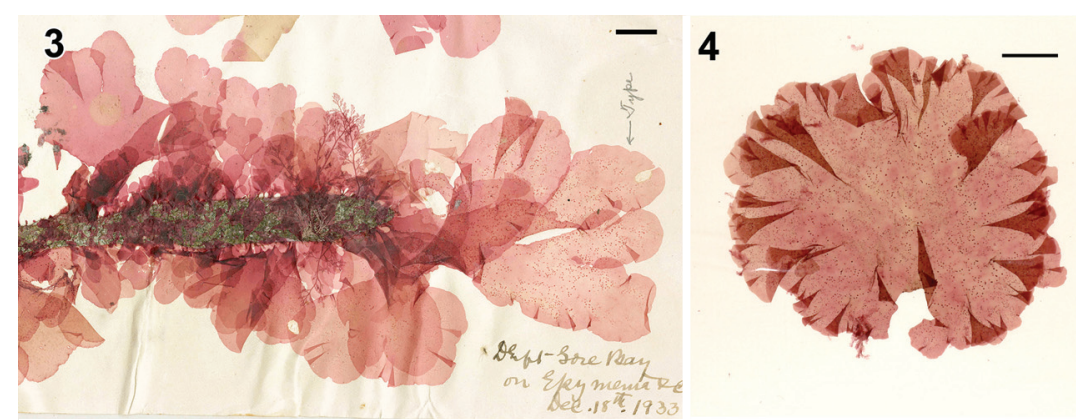

5

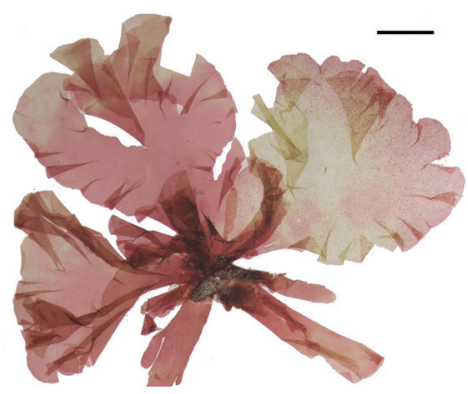

6

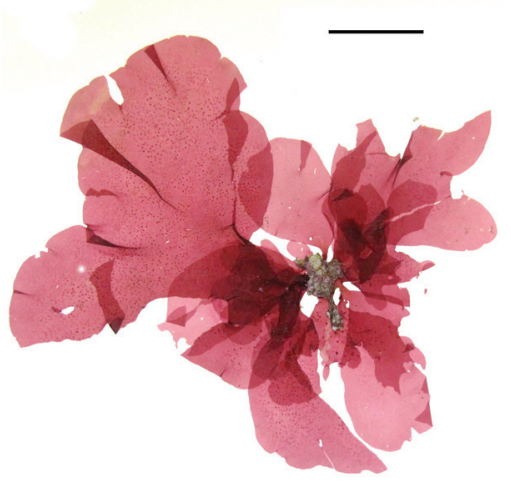

7

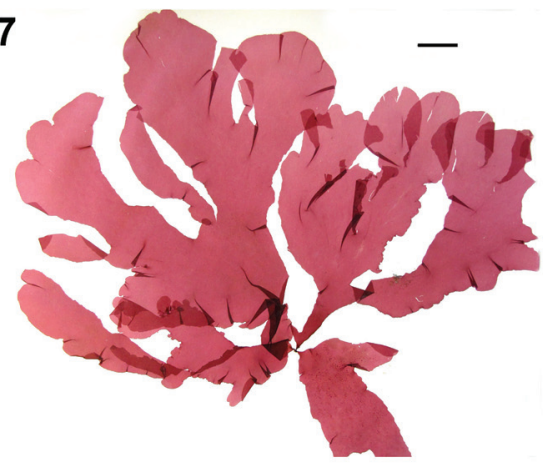

8
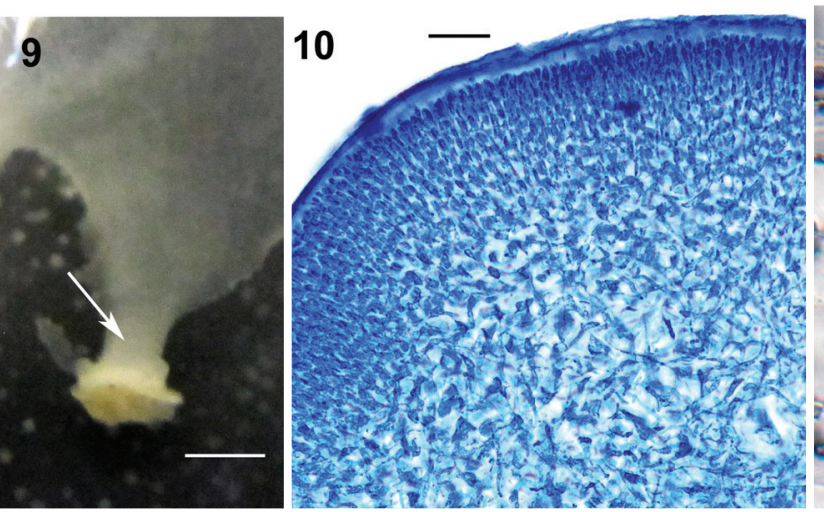

11
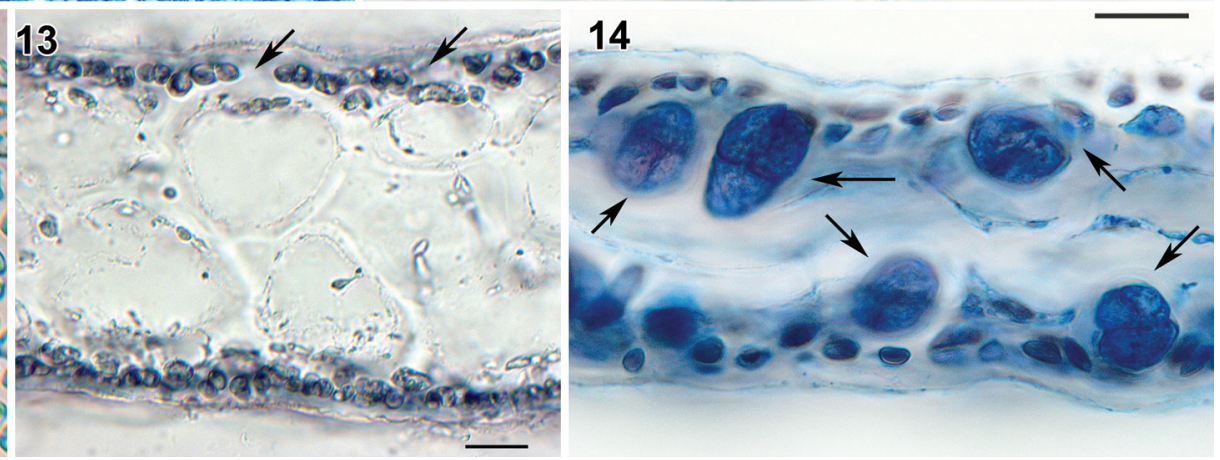

Figs. 3-14. Judithia delicatissima habit and vegetative structure. Fig. 3. Holotype, Gore Bay, Canterbury, cystocarpic (UC513609). Fig. 4. NCU 634646, Stewart Island, cystocarpic. Fig. 5. WELT A024374/A, cystocarpic, Marfell's Beach. Fig. 6. WELT A033080, cystocarpic, Marfell's Beach. Fig. 7. WELT A033081, tetrasporic, Marfell's Beach. Fig. 8. NCU 634639, tetrasporic, Stewart Island. Fig. 9. Blade enlarging abruptly from stipe (arrow). Fig. 10. Cross-section through a stipe. Fig. 11. Cross section through blade showing the medulla composed of a single layer of cell. Fig. 12. Cortical cells in surface view with some holes (arrows). Fig. 13. Cross-section through blade, note gap (arrows) in cortical layer. Fig. 14. Cross-section through tetrasporic blade bearing cruciately divided tetrasporangia (arrows). Figs 10-12, 14: aniline blue; Fig. 13: haematoxylin. Figs 9, 10, 12 (WELT A024374A); Fig. 14 (WELT A024374B); Figs 11, 13 (WELT A033083). Scale bars: Figs 3-8=2 cm; Fig. $9=1 \mathrm{~mm}$; Fig. $10=100 \mu \mathrm{m}$; Figs $11-14=20 \mu \mathrm{m}$.

Distribution: Cook Strait, South Island, Stewart Island.

Habit and anatomy: Mature blade morphology is variable (Figs 3-8) with one (Figs 4, 7) to 10 (Figs 5, 6) usually epiphytic blades arising abruptly from a
$<1 \mathrm{~mm}$ stipe, each anchored to the substratum by a small single discoid holdfast (Fig. 9). Thallus is soft and delicate but not lubricous, the blades $4-10 \mathrm{~cm}$ wide and $12-21 \mathrm{~cm}$ long, initially simple and rounded (Fig. 4) later becoming obcordate and splitting 


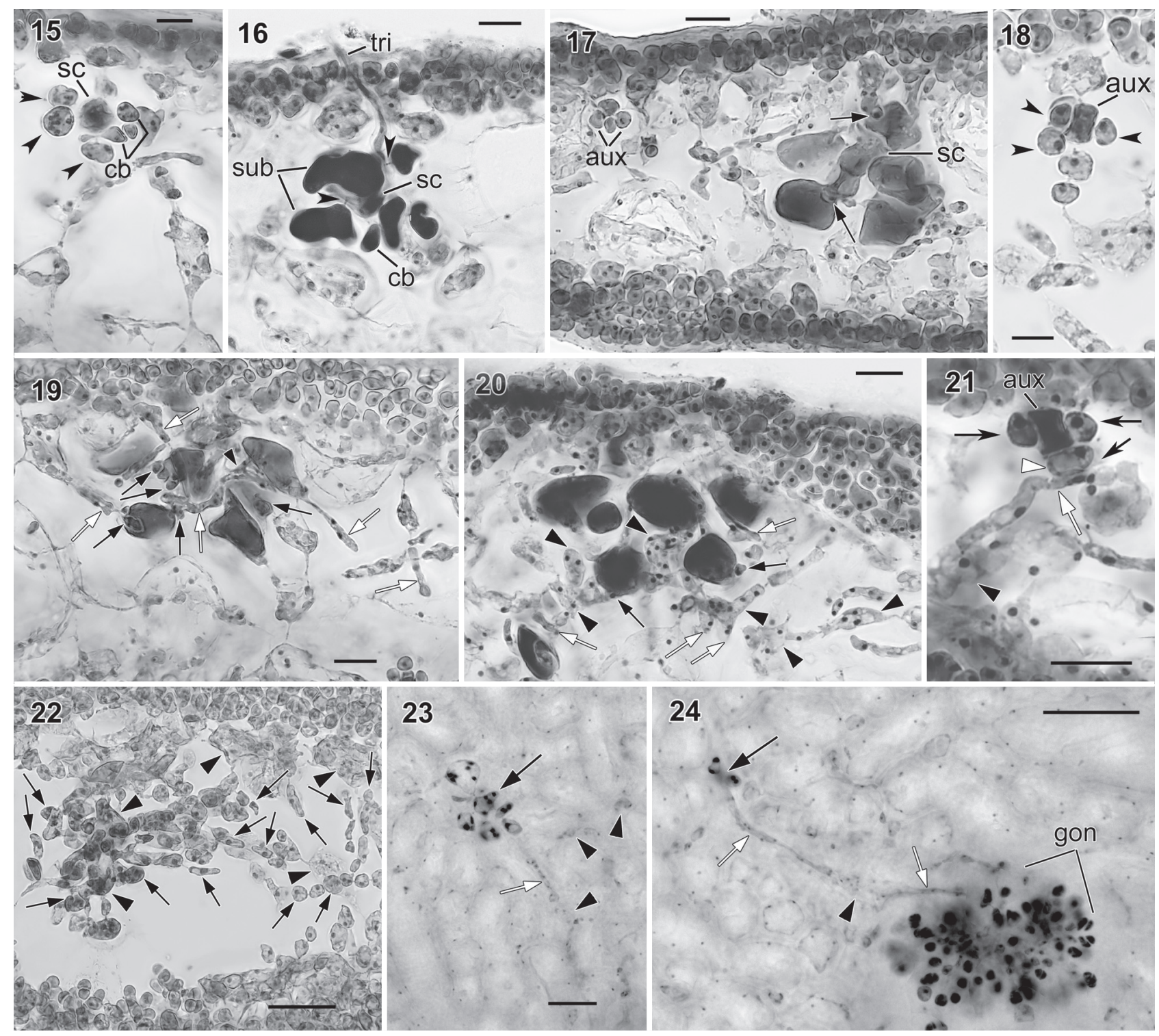

Figs. 15-24. Judithia delicatissima carpogonial branch/auxiliary cell systems and carposporophyte development. Fig. 15. Carpogonial branch system consisting of supporting cell (sc) bearing 3-celled carpogonial branch (cb) and three subsidiary cells (arrowheads). Fig. 16. Carpogonial branch system after fertilization with long trichogyne (tri) borne on carpogonial branch (cb). Note enlarged and stained darkly supporting cell (sc) and subsidiary cells (sub). Fig. 17. Early post-fertilization showing enlarged cells in carpogonial branch system in relation to smaller sized, nearby auxiliary cell system (aux). Note two minute cells (arrows), functioning as connecting cells, produced from two subsidiary cells but no cells cut off from supporting cell (sc). Fig. 18. Auxiliary cell system (aux), arrowheads indicate subsidiary cells. Fig. 19. Early post-fertilization stage with numerous connecting cells (black arrows) cut off from subsidiary cells. Note some connecting cells with pit connections to vegetative filaments (white arrows) produced from subcortical cell (arrowhead). Fig. 20. Later stage showing more connecting filaments (white arrows) produced from presumed diploidized subcortical cells and their derivatives (arrowheads) near carpogonial branch system. Note more connecting cells (black arrows) cut off from subsidiary cells. Fig. 21. Auxiliary cell system with one subsidiary cell (white arrowhead) receiving diploid nuclei via filament (white arrow) produced by nearby diploidized vegetative cell (black arrowhead). Fig. 22. Cross-section through young cystocarp showing young gonimoblast filaments (black arrows) produced from modified vegetative cells (black arrowheads) near auxiliary cell system. Fig. 23. Subsurface view of post-fertilization stage similar to Fig. 17 showing enlarged subsidiary cell in the carpogonial branch system (black arrow), darkly stained, modified subcortical cells (black arrowheads) nearby and connecting filament (white arrow). Fig. 24. Subsurface view of later stage showing young gonimoblast filaments (gon), remaining carpogonial branch system (black arrow), and connecting filaments (white arrows) produced from modified subcortical cell (black arrowhead). Figs 15-22: haematoxylin stain mounted in 50\% Hoyer's mounting medium; Figs 23-24: haematoxylin stain mounted in Piccolyte. Figs 15-22 (WELT A033083); Figs 23-24 (WELT A024374A). Scale bars: Figs 15,18=10 $\mu \mathrm{m}$; Figs 16, 17, 19-23=20 $\mu \mathrm{m}$; Fig. $24=$ $50 \mu \mathrm{m}$.

longitudinally one or more times (Figs 3, 5-8). Margins of blades are smooth and more or less undulate (Figs 3-8). Thalli are light rose-red in colour.
Stipes (Fig. 9) are composed of densely packed medullary filaments and a cortex of small cells arranged in anticlinal filaments (Fig. 10). Blades are 

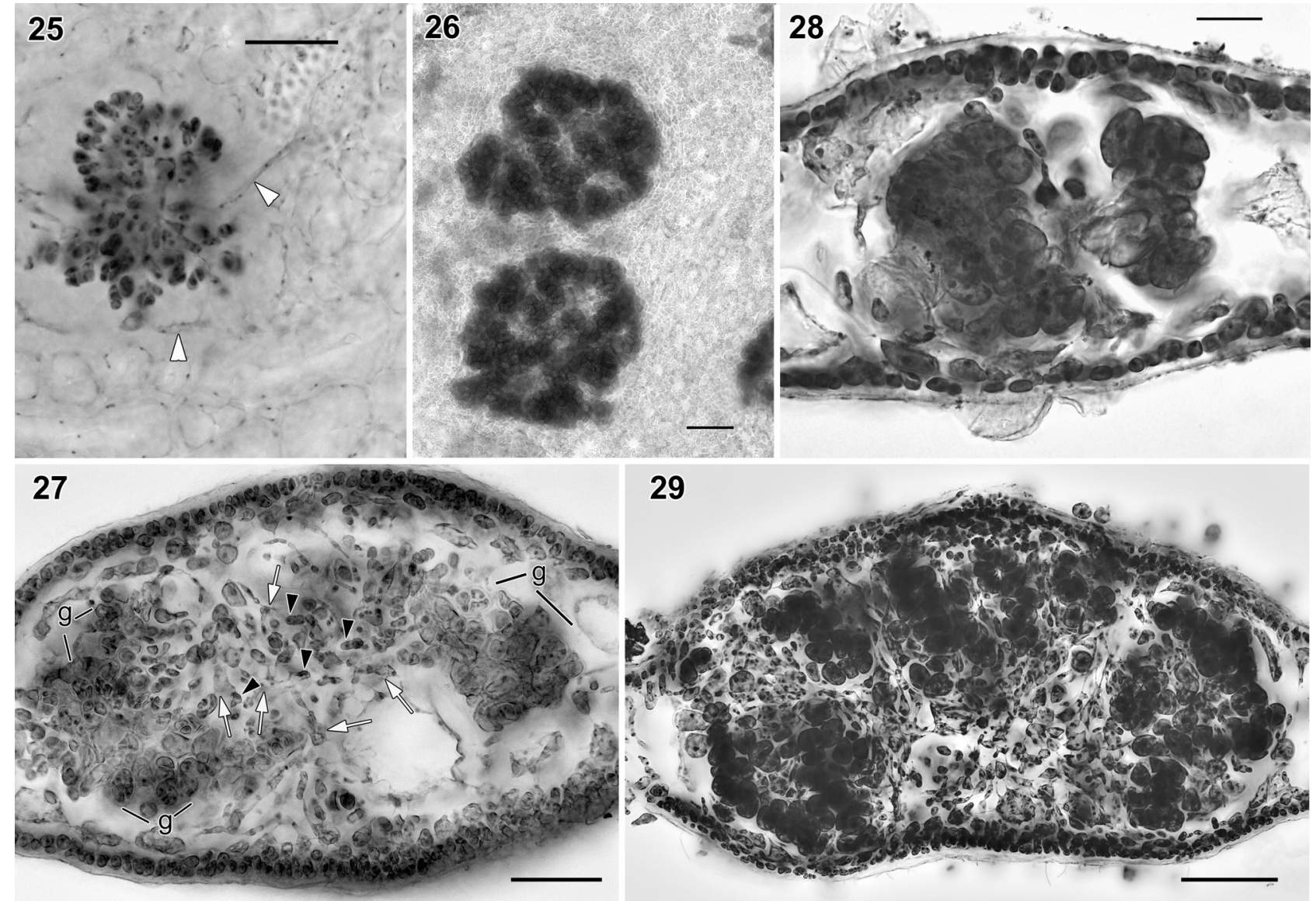

Figs. 25-29. Judithia delicatissima cystocarp development. Fig. 25. Young carposporophyte in subsurface view. Note connecting filaments (white arrowheads) produced from diploidized vegetative cells still present. Fig. 26. Carposporophyte in subsurface view. Fig. 27. Cross-section of immature cystocarp showing both young gonimoblast cells (black arrowheads) produced from diploidized vegetative cells (white arrows) and differentiating carposporangia in clusters (g). Fig. 28. Cross-section of mature cystocarp showing carposporangia in compact clusters. Fig. 29. Cross-section of mature cystocarp with carposporangia loosely arranged in clusters. Figs 25-26: haematoxylin stain mounted in piccolyte; Figs 27-29: haematoxylin stain mounted in 50\% Hoyer's mounting medium. Figs 25-26, 28 (WELT A024374A); Figs 27, 29 (WELT A033083). Scale bars: Figs 25, 27, $29=50 \mu \mathrm{m}$; Fig. $26 .=100 \mu \mathrm{m}$; Fig. $28=$ $20 \mu \mathrm{m}$.

$120-180 \mu \mathrm{m}$ thick medially but become progressively thin marginally to a single cell layer (Fig. 11). Surface cortical cells polygonal to sub-rounded in outline, 7-9 $\mu \mathrm{m}$ in diameter, loosely packed so that subcortical cells are visible in surface view (Fig. 12). The medulla is composed of one (Fig. 11) or two layers of large, ovoid, hyaline cells, 40-80 (110) $\mu \mathrm{m}$ long by $20-60$ $\mu \mathrm{m}$ wide interspersed with scattered, unaligned filaments of small cells (Figs 13-14). Refractive and stellate cells are absent.

Reproduction: Tetrasporophytes are isomorphic with gametophytes and bear cruciately divided tetrasporangia, $18-20 \mu \mathrm{m}$ wide by $25-28 \mu \mathrm{m}$ long (Fig. 14), scattered over blades except in basal parts. Carpogonial branch and auxiliary cell systems are produced from subcortical cells and develop thallus inwards, both systems being morphologically similar in their initial stages. Mature supporting cells bear three multinucleate, subsidiary cells and a single three-celled carpogonial branch (Fig. 15). After presumed fertilization, subsidiary cells enlarge, become lobed, stain darkly (Fig. 16) and produce connecting cells (Fig. 17). The auxiliary cell system is composed of an auxiliary cell and three or four subsidiary cells that are uninucleate (Fig. 18) and that occasionally cut off a second cell. Connecting filaments that each transfer a diploid nucleus from fertilized carpogonia directly to auxiliary cells were not seen. Instead, subsidiary cells of carpogonial branches cut off numerous, minute connecting cells (Fig. 17) that fuse with short filaments produced from subcortical or medullary cells in the vicinity of the carpogonial branch system (Fig. 19). As a result, more short filaments are progressively produced from modified vegetative cells (Fig. 20), and some reach a subsidiary cell in the auxiliary cell system to transfer putatively diploid nuclei (Fig. 21). Later, numerous gonimoblast filaments are produced from presumably diploidized vegetative cells in the vicinity of an auxiliary-cell system (Fig. 22); no gonimoblast initials or filaments are produced directly from the auxiliary cell and its subsidiary cells themselves. 
Cells in the carpogonial branch systems do not fuse together and the enlarged subsidiary cells remain distinct during gonimoblast development, and carpogonial branch systems, modified subcortical cells (Fig. 23), connecting filaments produced from modified subcortical vegetative cells, and gonimoblast cells are clearly visible in surface view (Fig. 24) after treatment with piccolyte mounting medium. Short connecting filaments are still visible through maturation of carposporophytes (Fig. 25). As carposporophyte development continues, terminal cells of gonimoblast filaments differentiate into compact clusters of carposporangia (Figs 26-27) separated by islands of vegetative tissue. Cystocarps initially form in patches (Fig. 28) and progressively become scattered more loosely (Fig. 29) across all blade surfaces distal to the basal region. Mature cystocarps $250-500 \mu \mathrm{m}$ in diameter lack both a differentiated pericarp and ostiole (Fig. 26). Spermatangial thalli were not found.

\section{Wendya D'Archino \& S.-M. Lin gen. nov.}

Description: Thalli erect, foliose, delicate, basally cuneate from a $2-5 \mathrm{~mm}$ stipe each with a small discoid holdfast. Blades tapering both apically and basally and sometimes producing marginal bladelets. Thalli composed of one layer of cortical cells, one layer of sparse subcortical cells and one or two layers of large, hyaline ovoid, medullary cells interspersed with small-celled filaments. Tetrasporophyte bearing cruciately divided tetrasporangia, isomorphic with gametophytes. Carpogonial branch system non-procarpic and monocarpogonial consisting of supporting cell bearing usually four multinucleate, subsidiary cells and a single three-celled carpogonial branch. Auxiliary cell bearing three or four subsidiary cells. After presumed fertilization, carpogonial branch subsidiary cells elongating and dividing 1-2 times. Connecting filaments produced from carpogonial branch supporting cell fusing with nearby auxiliary cell. Diploidized auxiliary cells cutting off short filaments that transfer diploid nuclei to neighbouring vegetative cells; these diploidized vegetative cells cutting off gonimoblast initials. Carposporophytes composed of diffuse gonimoblast filaments flanked by thin pericarps with ostioles. Subsidiary cells in auxiliary cells systems remain unchanged during carposporophyte development. Carposporangia developing in chains. Spermatangia not observed.

TYPE SPECIES: Wendya incisa D'Archino \& S.M. Lin sp. nov.

ETYMOLOGY: Named in honour of Prof. Wendy A. Nelson for her significant contributions to the marine flora of New Zealand.

\section{Wendya incisa D'Archino \& S.-M. Lin (Figs 30-58)}

Holotype: WELT A033085 (Fig. 30 Holotype indicated with an arrow), W.A. Nelson \& R. D'Archino, 7 October 2010, intertidal, epiphytic on Corallina officinalis Linnaeus.

Isotypes: (Fig. 30) WELT A033085.

Type locality: Mataikona, Masterton (Wellington Region), New Zealand.

Etymology: 'incisa' - cut into or through, refers to the cleft blades.

Specimens examined:

North Island: Owhiro Bay, Wellington ( $41^{\circ} 34.69^{\prime}$ $\left.\mathrm{S}, 174^{\circ} 75.80^{\prime} \mathrm{E}\right)$, 22 January $2006, R$. D'Archino, 5-10 m, WELT A024371; South Island: Brighton, Dunedin $\left(45^{\circ} 95.30^{\prime} \mathrm{S}, 170^{\circ} 32.69^{\prime} \mathrm{E}\right), 8$ December 2008, R. D'Archino, 3-6 m, WELT A024367, A024368, A024370; Karitane Beach, Dunedin (45 $\left.64.13^{\prime} \mathrm{S}, 170^{\circ} 66.93^{\prime} \mathrm{E}\right), 11$ December $2008, R$. D'Archino, 5-10 m, WELT A024369 and 4 January 2011, R. D'Archino, 5-10 m, WELT A033087; Black Head, Dunedin, $\left(45^{\circ} 55.48^{\prime} \mathrm{S}, 170^{\circ} 25.44^{\prime} \mathrm{E}\right), 5$ January 2011，R. D'Archino, WELT A033086; Mangamaunu, Kaikoura $\left(42^{\circ} 18.164^{\prime} \mathrm{S}, 173^{\circ}\right.$ 44.852' E), 7 January 2011, R. D'Archino \& W.A. Nelson, drift A033088; Stewart I.: Lee Bay, 28 May 1971, E. Conway \& N. Adams, WELT A006534.

Habitat and seasonality: Thalli occur from low intertidal to $10 \mathrm{~m}$ depth, epiphytic, epizoic or epilithic; most have been collected in early spring or summer, possibly seasonal. Occasionally found growing together with Judithia delicatissima.

Distribution: North and South Islands: Wellington Region, Cook Strait, Kaikoura, Otago Peninsula, Stewart Island, and the subantarctic: Antipodes Is., Snares Is., Campbell Is. and Auckland Islands.

Habit and anatomy: Thalli erect, foliose (Figs 3036 ), the blades soft but not lubricous, single or forming small clumps of $2-5$, each basally cuneate, and with a $2-5 \mathrm{~mm}$ stipe. Blades are attached to the substratum by a single discoid holdfast (Fig. 37) composed of rhizoidal filaments (Fig. 38). Young blades are lanceolate or ovate, $4-10 \mathrm{~cm}$ high by $0.5-2 \mathrm{~cm}$ wide, taper apically and have entire margins (Fig. 30). They are pale pink to greenish in the field but become darker pink when dried. Mature thalli (Figs 31-36) are dark red in colour and may attain lengths of $25 \mathrm{~cm}$ with blades cleft and sometimes bearing marginal proliferations (Fig. 32). Cortical cells in surface view are confluent, sub-rounded to polygonal, $7-9 \mu \mathrm{m}$ in diameter (Fig. 39) and completely obscure subcortical cells. Thalli range in thickness from 120-230 $\mu \mathrm{m}$ medially; blades become progressively thinner to a single cell layer at the margin (Fig. 40). Mature blades are composed of a single layer of surface cells, a layer of subcortical cells $18-40 \mu \mathrm{m}$ diameter and a medulla of one or two layers of loosely aggregated, hyaline 


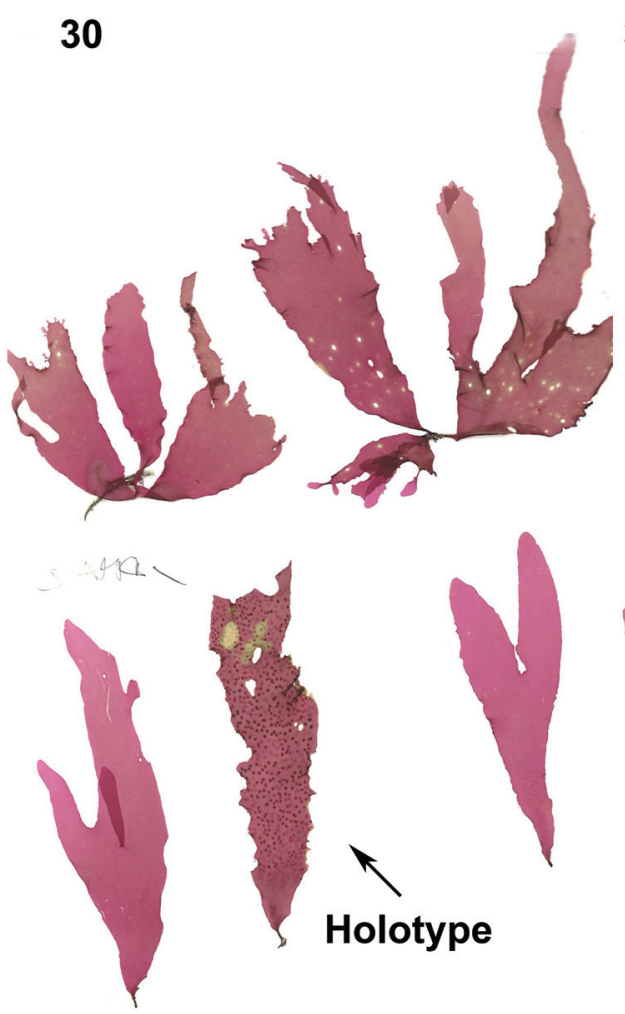

31

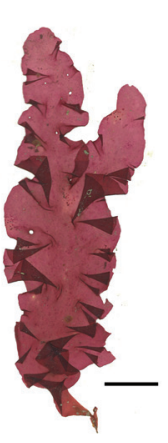

32

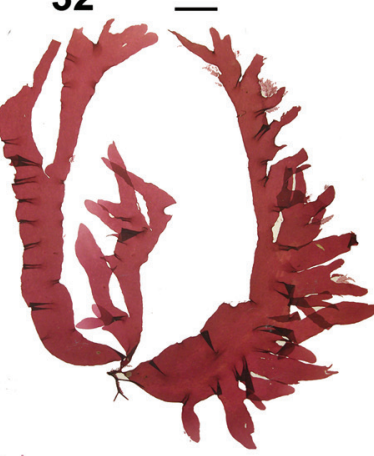

33

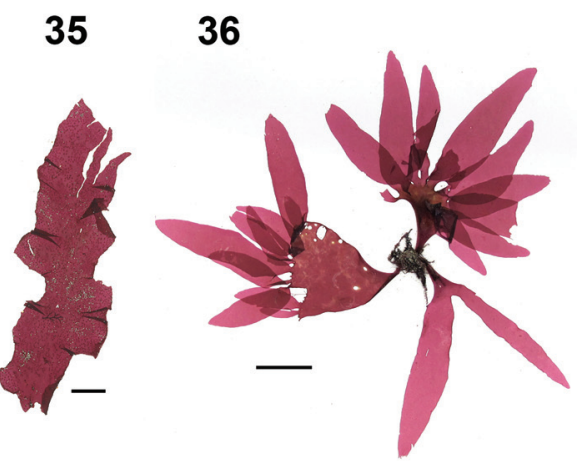

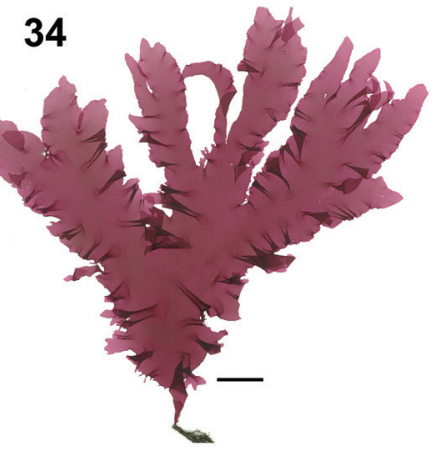
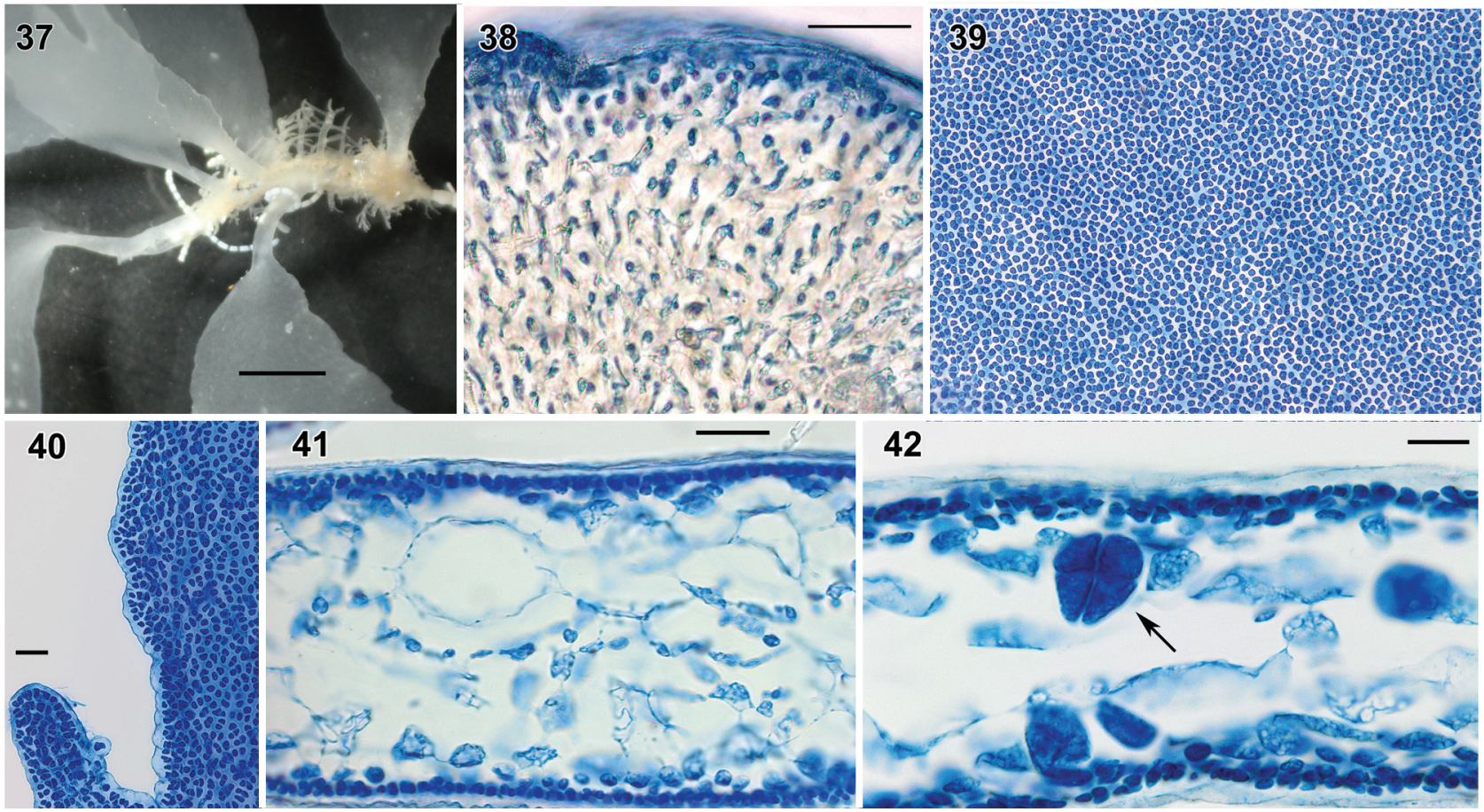

\section{2}

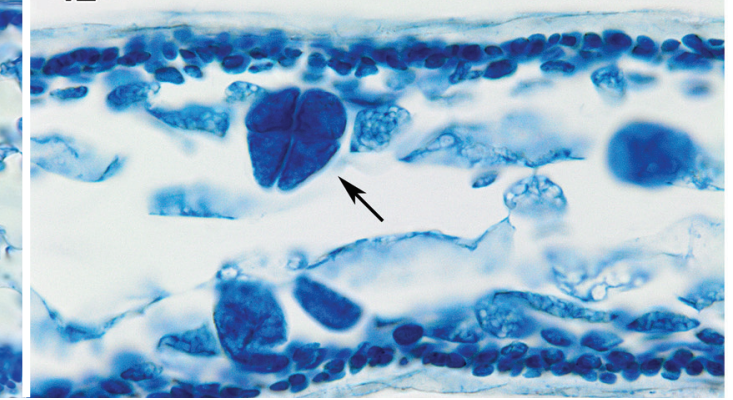

Figs. 30-42. Wendya incisa: habit and vegetative structure. Fig. 30. Holotype WELT A033085, cystocarpic (arrow) with isotypes, Mataikona, Wellington region. Fig. 31. WELT AS0095, Bluff, cystocarpic. Fig. 32. WELT A024367, tetrasporic, Brighton, Dunedin. Fig. 33. WELT A024368, tetrasporic, Brighton, Dunedin. Fig. 34. WELT AS0 615, tetrasporic, Moa Point, Wellington. Fig. 35. WELT ASN 155, cystocarpic Auckland Is. Fig. 36. WELT ASO 605, tetrasporic, Castel Point, Wellington region. Fig. 37. Basal parts of blades with cuneate base. Fig. 38. Stipe cross section. Fig. 39. Sub rounded to polygonal-shaped cortical cells in surface view. Fig. 40. Margin of blade. Fig. 41. Blade cross section. Fig. 42. Cross section through tetrasporic blade bearing cruciately arranged tetrasporangia. Figs 38-42: aniline blue. Figs. $37-42$ WELT A033085. Scale bars: Figs $30-36=2 \mathrm{~cm}$; Fig. $37=5$ mm; Figs $38-41=$ $50 \mu \mathrm{m}$; Fig. $42=20 \mu \mathrm{m}$.

cells, $50-105 \mu \mathrm{m}$ in diameter interspersed with filaments of small cells (Fig. 41). Refractive and stellate cells are absent.
Reproduction: Tetrasporophytes (Figs 32, 33) and female gametophytes (Fig. 30) are isomorphic. Tetrasporangia are cruciately divided (Fig. 42), 

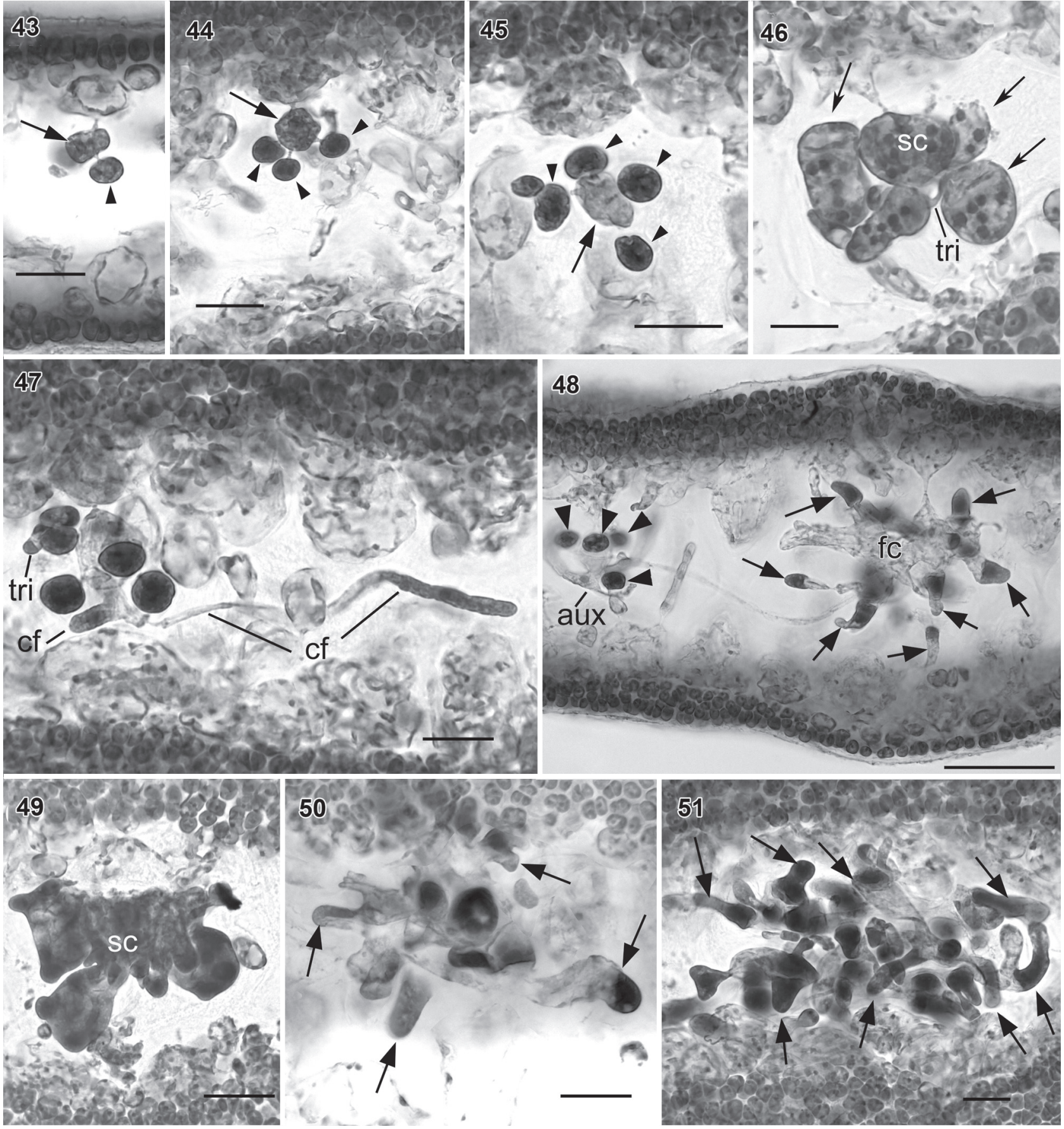

Figs. 43-51. Wendya incisa carpogonial branch/auxiliary cell system and carposporophyte development (WELT A033085, Mataikona, northeastern Wellington Region, New Zealand, haematoxylin stain). Fig. 43-45. Early formation of carpogonial branch/auxiliary cell system (arrow) bearing subsidiary cells (arrowheads). Fig. 46. Multinucleate carpogonial branch system with three subsidiary cells (arrows). Note trichogyne (tri) circling around supporting cell (sc). Fig. 47. Early postfertilization showing carpogonial branch system producing connecting filaments (cf). Fig. 48. Later stage of carpogonial branch system showing connecting filament from carpogonial branch system with pit-connection to auxiliary cell system (aux), bearing four subsidiary cells (arrowheads). Note subsidiary cells derived from supporting cell divided transversely and fused with supporting cell (arrows) forming fusion cell (fc). Fig. 49. Aborted carpogonial branch system noting that the supporting cell and the subsidiary cells fused together. Figs 50-51. Further development of carpogonial branch system. Subsidiary cells (arrows) elongated first (Fig. 50) then branched (Fig. 51). Scale bars: Figs $42-47 \& 49-51=20 \mu \mathrm{m}$; Fig. $48=50 \mu \mathrm{m}$.

$20-32 \mu \mathrm{m}$ in diameter, and scattered over blades except at their bases. Carpogonial branch and auxiliary cell systems are initiated laterally from subcortical cells, both cellular complexes being indistinguishable in early stages of formation (Figs 43, 44). Each consists of a supporting or auxiliary cell bearing three or four multinucleate, undivided, subsidiary cells (Figs 45-46) prior to fertilization. Supporting cells bear a single three-celled carpogonial branch and three subsidiary cells (Fig. 46). After presumed 

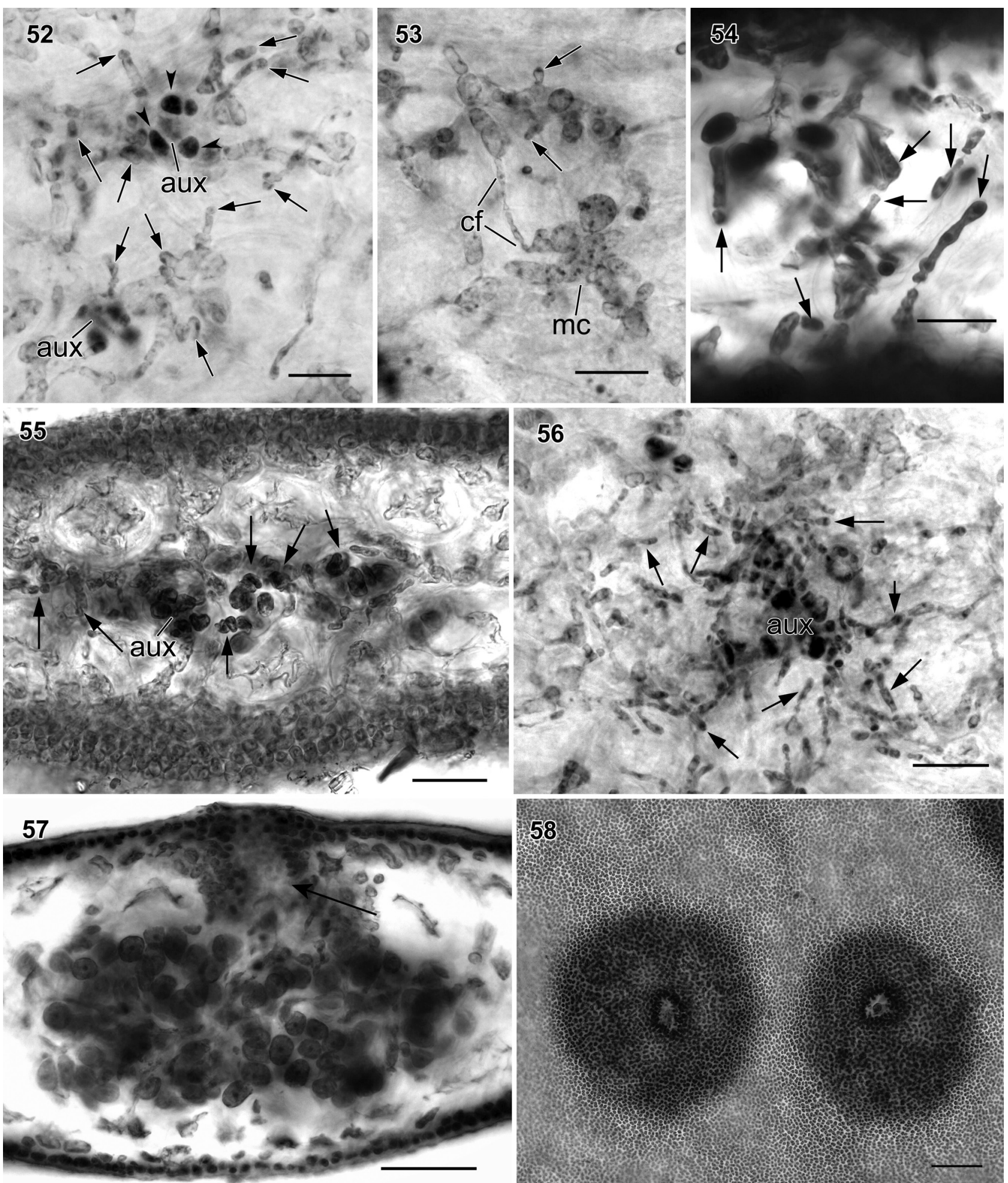

Figs. 52-58. Wendya incisa cystocarp development (WELT A033085, Mataikona, northeastern Wellington, New Zealand). Fig. 52. Subsurface view of young gonimoblast filaments (arrows) produced from modified vegetative cells near two auxiliary cell systems. Note subsidiary cells remain distinct. Fig. 53. Close-up of stage similar to Fig. 52 showing modified vegetative cells (mc) connected to neighbouring vegetative cell through short connecting filament (cf). Both modified vegetative cells produce gonimoblast filament initials (arrows). Fig. 54. Cross-section through post-fertilization stage similar to Fig. 52 showing young gonimoblast filaments (arrows) produced from modified vegetative cells near two auxiliary cell systems; subsidiary cells remain distinct. Fig. 55. Crosssection through young cystocarp showing remaining auxiliary cell system and developing gonimoblast filaments (arrows). Fig. 56. Subsurface view of young cystocarp similar to Fig. 55 showing remaining auxiliary cell system (aux) and developing gonimoblast filaments (arrows). Fig. 57. Cross-section through mature cystocarp with ostiole (arrow). Fig. 58. Carposporophyte in surface view showing the ostioles. Figs 52-53, 56: haematoxylin stain mounted in piccolyte; Figs 54-55, 57-58: haematoxylin stain mounted in $50 \%$ Hoyer's mounting medium. Scale bars: Figs $52-54=20 \mu \mathrm{m}$; Figs 55, $56=50 \mu \mathrm{m}$; Fig. $57=100 \mu \mathrm{m}$. 
fertilization, the supporting cell enlarges slightly and cuts off at least two non-septate, unbranched connecting filaments (Fig. 47) that carry diploid nuclei to a nearby auxiliary cell (Fig. 48). Meanwhile, the supporting cell enlarges and fuses with surrounding subsidiary cells resulting in a large fusion cell. At this stage, the fusion cell initiates filaments that extend in multiple directions (Figs 50-51). Seemingly aborted carpogonial branch systems form a large, lobed, fusion cell (Fig. 49). Diploidized auxiliary cells cut off multiple gonimoblast initials that divide into short gonimoblast filaments that fuse with adjacent vegetative cells, these in turn producing further gonimoblasts (Figs 52, 53). Auxiliary cell systems do not directly produce gonimoblast filaments (Fig. 54) and remain distinct (Figs 55, 56) during carposporophyte development. As cystocarp development proceeds, more gonimoblast filaments are produced from modified subcortical and medullary cells (Figs 55, 56). In general, gonimoblast filaments are relatively diffuse (compared with Judithia), and most gonimoblast cells differentiate into carposporangia (Fig. 57). Mature cystocarps are $400-500 \mu \mathrm{m}$ in diameter and include a well differentiated, ostiolate pericarp (Fig. 58). Carposporangia do not form in clusters.

\section{DISCUSSION}

Phylogenetic analyses of DNA sequences of $r b c \mathrm{~L}$ and combined $r b c \mathrm{~L}$ and LSU show that the foliose specimens previously identified in New Zealand as the endemic Pugetia delicatissima are in fact two distinct evolutionary lineages that are only distantly related to the type species of Pugetia. This study highlights how DNA sequences of particular markers can reveal unexpected cryptic diversity indicative of not only distinct species but even distinct genera.

The phylogenetic placement of Judithia and Wendya in different clades led us to focus on differences in habit and vegetative and reproductive anatomy that show the two genera are not fully cryptic entities. Judithia usually has rounded to oblong blades that mostly expand abruptly from the short stipe (although sometimes the base is more attenuate), while Wendya has blades with tapering apices and cuneate bases borne on a longer stipe; the cortical cells are loosely arranged in Judithia and more compacted in Wendya; on cystocarpic thalli carposporangia occur in clusters and pericarps and ostioles are absent in Judithia in contrast to carposporangia not clustered and pericarps and ostioles present in Wendya.

These two genera also differ in numerous pre- and post-fertilization stages, and all of these differences are presented in Table 1. Although we failed to amplify DNA from the cystocarpic holotype of $P$. delicatissima, we regard it as the type species of
Judithia because it has clustered carposporangia and lacks pericarps and ostioles-characters readily determined from dried herbarium specimens (Table 1).

Both species have a similar distribution from Stewart Island in the south, northward along the eastern coast of the South Island to the Marlborough Region and Cook Strait. Wendya, however, extends to slightly further north to the North Island in the Wellington region. They share similar lower-intertidal to subtidal habitats on open, exposed coasts and have been collected only rarely in sheltered areas. Herbarium records (e.g. WELT A025186) sometimes show thalli of both species occurring on a single host such as Gigartina ancistroclada Montagne. Dr Elsie Conway, who annotated WELT A025186 collected with Nancy Adams in 1971, remarked on some morphological differences between the two 'taxa' and marked the thalli on sheet 'A' (with a question mark, this conforming to Wendya) and ' $\mathrm{B}$ ' as true ' $P$. delicatissima?' (this conforming to Judithia).

Molecular analyses showed Judithia closely related to a species erroneously called Callophyllis variegata in New Zealand that will be included in a treatment of the branched Kallymeniaceae from New Zealand (D'Archino unpublished data). Wendya, in contrast, was sister to Callophyllis including the generitype species $C$. variegata from Chile, but differs in diploidization and gonimoblast features that support its recognition as a distinct genus.

Genera of Kallymeniaceae have been divided into non-procarpic genera, where carposporophyte formation involves an auxiliary cell branch system separate from the carpogonial branch system (e.g. Kallymenia and Pugetia), and procarpic genera, where the carpogonial branch system gives rise to the carposporophyte directly after fertilization and no auxiliary branch system is present, e.g. Callophyllis (Norris, 1957). The situation however is more complex and elaborate interactions and fusions between vegetative and reproductive cells during carposporophyte development occur (e.g. in Kallymenia reniformis (Turner) J. Agardh, Hommersand and Ott 1970). Hommersand \& Ott (1970) observed connecting filaments fusing with the auxiliary cell, as well as with some surrounding vegetative cells, and gonimoblast initiated in scattered pockets from vegetative cells in the vicinity of the auxiliary cell system. This observation was not confirmed by Womersley \& Norris (1971) on Australian genera nor by Rodríguez-Prieto \& Hommersand (2009) on species of Kallymenia (including $K$. reniformis) although the last authors provided evidence that gonimoblast cells may link up with gametophytic cortical and medullary cells and produce secondary gonimoblast filaments. The connecting filaments in species of Kallymenia (Rodríguez-Prieto \& Hommersand, 2009) fused 
Table 1. Morphological comparisons among Judithia, Wendya and Pugetia delicatissima sensu Norris (1957).

\begin{tabular}{|c|c|c|c|}
\hline & Judithia & Wendya & Pugetia delicatissima sensu Norris \\
\hline Blade shape & $\begin{array}{l}\text { Initially rounded becoming elongated, } \\
\text { with rounded apices }\end{array}$ & $\begin{array}{l}\text { Initially lanceolate becoming elongated } \\
\text { with tapering apices }\end{array}$ & $\begin{array}{l}\text { Blades branching dichotomously once or } \\
\text { several times obcordate in young plant }\end{array}$ \\
\hline Stipe & $\begin{array}{l}\text { Blades enlarge abruptly from stipe less } \\
\text { than } 1 \mathrm{~mm} \text { above holdfast }\end{array}$ & $\begin{array}{l}\text { Blades cuneate at the base, arising from a } \\
2-5 \mathrm{~mm} \text { long stipe }\end{array}$ & $\begin{array}{l}\text { Blades tapering gradually to a narrow stipe } \\
\text { (not exceeding } 1 \mathrm{~mm} \text { in length) }\end{array}$ \\
\hline $\begin{array}{l}\text { Arrangement of } \\
\text { cortical cells }\end{array}$ & $\begin{array}{l}\text { Polygonal to sub rounded, loosely } \\
\text { arranged }\end{array}$ & Polygonal-shaped, compactly arranged & Polygonal to sub-rounded? \\
\hline $\begin{array}{l}\text { Carpogonial } \\
\text { branch } \\
\text { system }\end{array}$ & $\begin{array}{l}\text { Supporting cell bearing a single } 3 \text {-celled } \\
\text { carpogonial branch and } 3 \text { subsidiary } \\
\text { cells }\end{array}$ & $\begin{array}{l}\text { Supporting cell bearing a single } 3 \text {-celled } \\
\text { carpogonial branch and } 4 \text { subsidiary } \\
\text { cells }\end{array}$ & $\begin{array}{l}\text { Supporting cell bearing a single } \\
\text { carpogonial branch and } 2 \text { or } 3 \text { one or } \\
\text { two-celled subsidiary branches }\end{array}$ \\
\hline $\begin{array}{l}\text { Auxiliary cell } \\
\text { system }\end{array}$ & $\begin{array}{l}\text { Auxiliary cell and three or four subsidiary } \\
\text { cells that occasionally cut off a second } \\
\text { cell }\end{array}$ & $\begin{array}{l}\text { Auxiliary cell bearing four subsidiary } \\
\text { cells; subsidiary cells not dividing pre- } \\
\text { or post-fertilization }\end{array}$ & $\begin{array}{l}\text { Subsidiary branch of the auxiliary cell } \\
\text { group is composed of one or two cells }\end{array}$ \\
\hline $\begin{array}{l}\text { After } \\
\quad \text { fertilization }\end{array}$ & $\begin{array}{l}\text { Carpogonial branch subsidiary cells } \\
\text { enlarge and become lobed and } \\
\text { diploidized and produce small } \\
\text { connecting cells }\end{array}$ & $\begin{array}{l}\text { Carpogonial branch subsidiary cells } \\
\text { elongate and divide once or twice and } \\
\text { becoming antler-like }\end{array}$ & $\begin{array}{l}\text { Fusion cells produce non-septate } \\
\text { connecting filaments that grow into the } \\
\text { medullary tissue }\end{array}$ \\
\hline $\begin{array}{l}\text { Connecting } \\
\text { filaments }\end{array}$ & $\begin{array}{l}\text { Absent, connecting cells produce short } \\
\text { filaments that fuse with modified } \\
\text { subcortical or medullary cells; these in } \\
\text { turn produce additional short, } \\
\text { filaments that diploidize subsidiary } \\
\text { cells of the auxiliary system }\end{array}$ & $\begin{array}{l}\text { Present, connecting filaments produced } \\
\text { from carpogonial branch supporting } \\
\text { cell and fuse with the auxiliary cell }\end{array}$ & $\begin{array}{l}\text { Tips of connecting filaments fuse with } \\
\text { auxiliary cells }\end{array}$ \\
\hline $\begin{array}{l}\text { Gonimoblast } \\
\text { origin }\end{array}$ & $\begin{array}{l}\text { Gonimoblast filaments form from } \\
\text { modified vegetative cells in vicinity of } \\
\text { an auxiliary cell system }\end{array}$ & $\begin{array}{l}\text { Diploidized auxiliary cells cut off short } \\
\text { filaments that transfer diploid nuclei to } \\
\text { neighbouring vegetative cells; these } \\
\text { diploidized vegetative cells in vicinity } \\
\text { of auxiliary cell systems cut off } \\
\text { gonimoblast initials that then elongate } \\
\text { into gonimoblast filaments }\end{array}$ & $\begin{array}{l}\text { From a protuberance of the auxiliary cell or } \\
\text { from the terminal part of the connecting } \\
\text { filament that subsequently becomes } \\
\text { separated from the rest of the filaments }\end{array}$ \\
\hline Carposporangia & in clusters & not in clusters & in clusters \\
\hline Pericarp & absent & present & absent \\
\hline Ostiole & absent & present & absent \\
\hline
\end{tabular}

with an auxiliary cell or, more often, fused with the auxiliary cell laterally and continued to grow and produce branched gonimoblast filament laterally along their length (e.g. Kallymenia reniformis).

Judithia delicatissima has a distant carpogonial and auxiliary cells system as shown in Norris (1957, as P. delicatissima) and herein (see Figs 17, 21). Norris's (1957) interpretation was that gonimoblast filaments in J. delicatissima were produced either from a protuberance of the auxiliary cell or from the terminal part of a connecting filament in the vicinity of the auxiliary cell system (Figs 6G, p. 274). However, we found that after presumed fertilization supporting cells of carpogonial branch systems cut off small cells that gave rise to short connecting filaments that connected with modified, darkly stained subcortical or medullary cells and presumably deposited zygote derived nuclei in these vegetative cells. These cells in turn produced additional short connecting filaments that diploidized subsidiary cells of the auxiliary-cell system but did not fuse with the auxiliary cell itself. Numerous short filaments were produced from the diploidized vegetative cells near the auxiliary cell system, but only some of them were transformed into gonimoblast filaments. Presumably, the auxiliary cell system plays an important role in transforming the short filaments into gonimoblast filaments. This mechanism is very similar to that reported by Lin et al. (2012a) in Callophyllis concepcionensis Arakaki, Alveal \& M. E. Ramírez, where, after fertilization, large numbers of secondary subcortical and medullary cells are produced and the diploid nuclei are transferred from lobes of the subsidiary cells through connecting cells from one vegetative cell to another. As a result, diploidized vegetative cells cut off gonimoblast initials that divide multiple times to form filaments that produce carposporangia and that surround the central primary medullary cells.

Wendya incisa is also non-procarpic and has connecting filaments and auxiliary cell systems typical of many Kallymeniaceae. It is, however similar to Callophyllis concepcionensis and Judithia delicatissima in having diploidized vegetative cells that cut off gonimoblast initials. In Cirrulicarpus carolinensis Hansen (1977) short celled-filaments that formed carposporangia developed from subcortical cells located next or quite distant to a carpogonial branch system. Hansen (1977) noted 'that the only visible connection between the two is through pre-existing vegetative cells and their pit-connections - an unlikely path to the transfer of diploid nucleus'. Involvement of 
vegetative cells in post-fertilization events was also seen in the genus Stauromenia D'Archino \& W.A. Nelson (D'Archino et al., 2012).

Separation of the existing genera of Kallymeniaceae requires a combination of reproductive characters, some easy to document, e.g., mono- or polycarpogonial branch systems, morphology of mature cystocarps; others more difficult to observe and interpret such as early stages of post-fertilization and the origin of gonimoblast filaments. At least two ways of transferring diploid nuclei (produced apparently from fertilized carpogonia), evolved in the family, one using connecting filaments and another, well documented in this study and in Lin et al. (2012a), using modified (i.e. diploidized) vegetative cells. Differences in interpretation of post-fertilization development (Norris, 1957; Hommersand \& Ott, 1970; Hansen, 1977; Rodriguez-Prieto \& Hommersand, 2009; Lin et al., 2012a) argue for ongoing examination of this complex process, as well as its utility in segregating genera and species in the Kallymeniaceae.

\section{ACKNOWLEDGEMENTS}

Kathy Ann Miller (UC), Jenn Dalen and Antony Kusabs (WELT) are thanked for assistance with herbarium specimens and registration numbers. We thank Y.S. Chiou for assisting with DNA sequencing for some species and Max Hommersand for sharing his knowledge of the Kallymeniaceae. PWG thanks Wilson Freshwater, DNA Analysis Core Facility, University of North Carolina, Wilmington for sequencing support and Todd Vision, University of North Carolina, Chapel Hill for research space and equipment. A portion of this research was completed while PWG was a visiting professor at the Friday Harbor Labs, University of Washington.

\section{DISCLOSURE STATEMENT}

No potential conflict of interest was reported by the author(s).

\section{FUNDING}

This research was funded by NIWA under Coasts and Oceans Research Programme 2 Marine Biological Resources: Discovery and definition of the marine biota of New Zealand (COBR1301-1501) and a research grant (NSC 102-2628-B-019 -002 -MY3) for SML.

\section{SUPPLEMENTARY INFORMATION}

The following supplementary material is accessible via the Supplementary Content tab on the article's online page at http://10.1080/09670262.2015.1104557
Supplementary Table 1. List of representative specimens examined, collector, location,date, voucher, GenBank accession numbers and image.

\section{AUTHOR CONTRIBUTIONS}

R. D'Archino framing experimental design, laboratory and field work, data analysis and interpretation, manuscript preparation. S.-M. Lin laboratory work, data analysis and interpretation, manuscript preparation. P. W. Gabrielson laboratory work, data interpretation, editing G. C. Zuccarello laboratory work, molecular analysis and interpretation, editing.

\section{REFERENCES}

Adams, N.M. (1994). Seaweeds of New Zealand. Canterbury University Press, Christchurch.

Adams, N.M., Conway, E. \& Norris, R.E. (1974). The marine algae of Stewart Island. Records of the Dominion Museum, 8: 145-245.

Clarkston, B.E. \& Saunders, G.W. (2012). An examination of the red algal genus Pugetia (Kallymeniaceae, Gigartinales) with descriptions of Salishia firma gen. et comb. nov., Pugetia cryptica sp. nov., and Beringia wynnei sp. nov. Phycologia, 51: 33-61.

Dalen, J. \& Nelson, W.A. (2013). http://www.tepapa.govt.nz/ SiteCollectionDocuments/Te.Papa. list.of.marine.macroalgae. Rhodophyta.pdf

D'Archino, R., Nelson, W.A. \& Zuccarello, G.C. (2010). Psaromenia (Kallymeniaceae, Rhodophyta): a new genus for Kallymenia berggrenii. Phycologia, 49: 73-85.

D'Archino, R., Nelson, W.A. \& Zuccarello, G.C. (2011). Diversity and complexity in New Zealand Kallymeniaceae (Rhodophyta): recognition of the genus Ectophora and description of E. marginata sp. nov. Phycologia, 50: 241-255.

D'Archino, R., Nelson, W.A. \& Zuccarello, G.C. (2012). Stauromenia australis, a new genus and species in the family Kallymeniaceae (Rhodophyta) from southern New Zealand. Phycologia, 51: 451-460.

D’Archino, R., Nelson, W.A. \& Zuccarello, G.C. (2014). Amalthea and Galene, two new genera of Halymeniaceae (Rhodophyta) from New Zealand. Botanica Marina, 57: 185-201.

Darriba, D., Taboada, G.L., Doallo, R. \& Posada, D. (2012). jModelTest 2: more models, new heuristics and parallel computing. Nature Methods, 9: 772.

Felsenstein, J. (1985). Confidence limits on phylogenies: an approach using the bootstrap. Evolution, 39: 783-791.

Freshwater, D.W. \& Rueness, J. (1994). Phylogenetic relationship of some European Gelidium (Gelidiales, Rhodophyta) species, based on $r b c \mathrm{~L}$ nucleotide sequence analysis. Phycologia, 33: 187-194.

Guindon, S. \& Gascuel, O. (2003). A simple, fast and accurate method to estimate large phylogenies by maximum-likelihood. Systematic Biology, 52: 696-704.

Guiry, M.D. \& Guiry, G.M. (2015). AlgaeBase. World-wide electronic publication. National University of Ireland, Galway. Available at http://www.algaebase.org. [Accessed 25 March 2015].

Hansen, G.I. (1977). Cirrulicarpus carolinensis, a new species in the Kallymeniaceae (Rhodophyta). Occasional Papers of the Farlow Herbarium Harvard University, 12: 1-22.

Harper, J.T. \& Saunders, G.W. (2001). Molecular systematics of the Florideophyceae (Rhodophyta) using nuclear large and small subunit rDNA sequence data. Journal of Phycology, 37: 1073-1082. Hommersand, M.H. \& Ott, D.W. (1970). Development of the carposporophyte of Kallymenia reniformis (Turner) J. Agardh. Journal of Phycology, 6: 322-331.

Hommersand, M.H., Moe, R.L., Amsler, C.D. \& Fredericq, S. (2009). Notes on the systematics and biogeographical relationships of Antarctic and sub-Antarctic Rhodophyta with descriptions of four new genera and five new species. Botanica Marina, 52: 509-534.

Hommersand, M.H., Leister, G.L., Ramírez, M.E., Gabrielson, P.W. \& Nelson, W.A. (2010). A morphological and phylogenetic study of Glaphyrosiphon gen. nov. (Halymeniaceae, Rhodophyta) based 
on Grateloupia intestinalis with descriptions of two new species: Glaphyrosiphon lindauri from New Zealand and Glaphyrosiphon chilensis from Chile. Phycologia, 49: 554-573.

Hughey, J.R., Silva, P.C. \& Hommersand, M.H. (2001). Solving taxonomic and nomenclatural problems in Pacific Gigartinaceae (Rhodophyta) using DNA from type material. Journal of Phycology, 37: 1091-1109.

Katoh, K., Misawa, K., Kuma, K. \& Miyata, T. (2002). MAFFT: a novel method for rapid multiple sequence alignment based on fast Fourier transform. Nucleic Acids Research, 30: 3059-3066.

Kraft, G.T. (1976). Morphology of Placentophora (Solieriaceae, Gigartinales: Rhodophyta), a new genus based on Sarcodiotheca colensoi from New Zealand. Journal of Phycology, 11: 399-410.

Lin, S.-M., Fredericq, S. \& Hommersand, M.H. (2001). Systematics of the Delesseriaceae (Ceramiales, Rhodophyta) based on large subunit rDNA and $r b c \mathrm{~L}$ sequences, including the Phycodryoideae, subfam. nov. Journal of Phycology, 37: 881-899.

Lin, S.-M., Hommersand, M.H. \& Fredericq, S. (2004). Two new species of Martensia (Delesseriaceae, Rhodophyta) from Kenting National Park, southern Taiwan. Phycologia, 43: 13-25.

Lin, S.-M., D'Archino, R. \& Hommersand, M.H. (2012a). A new method of cystocarp development in red algal genus Callophyllis (Kallymeniaceae) from Chile. Journal of Phycology: 48: 784-792.

Lin, S.-M., Nelson, W.A. \& Hommersand, M.H. (2012b). Hymenenopsis heterophylla gen. et sp. nov. (Delesseriaceae, Rhodophyta) from New Zealand, based on a red alga previously known as Hymenena palmata f. marginata sensu Kylin, with emphasis on its cystocarp development. Phycologia 51: 62-73.

Nelson, W.A. (2012). Phylum Rhodophyta: red algae. In New Zealand Inventory of Biodiversity. Vol. 3 (Gordon, D.P., editor), pp. 327-346. Canterbury University Press, Canterbury.

Nelson, W.A., Leister, G.L. \& Hommersand, M.H. (2011). Psilophycus alveatus gen. et comb. nov., a basal taxon in the Gigartinaceae (Rhodophyta) from New Zealand. Phycologia, 50: 219-231.
Norris, R.E. (1957). Morphological studies on the Kallymeniaceae. University of California Publications in Botany, 28: 251-333.

Rambaut, A. \& Drummond, A.J. (2007). Tracer v1.4. Available from http://beast.bio.ed.ac.uk/Tracer.

Rodriguez-Prieto, C. \& Hommersand, M.H. (2009). Behaviour of the nuclei in pre- and postfertilization stages in Kallymenia (Kallymeniaceae, Rhodophyta). Phycologia, 48: 138-155.

Ronquist, F. \& Huelsenbeck, J.P. (2003). MrBAYES 3: Bayesian phylogenetic inference under mixed models. Bioinformatics, 19: 1572-1574.

Saunders, G.W., Chiovitti, A. \& Kraft, G.T. (2004). Small-subunit rDNA sequences from representative of selected families of the Gigartinales and Rhodymeniales (Rhodophyta). 3. Delineating the Gigartinales sensu stricto. Canadian Journal of Botany, 82: 43-74.

Stamatakis, A. (2006). RAxML-VI-HPC: Maximum likelihoodbased phylogenetic analyses with thousands of taxa and mixed models. Bioinformatics, 22: 2688-2690.

Thiers, B. (2015). [continuously updated]. Index Herbariorum: A Global Directory Of Public Herbaria and Associated Staff. New York Botanical Garden's Virtual Herbarium. Available at http:// sweetgum.nybg.org/ih/. [Accessed on 25 March 2015].

Wittmann, W. (1965). Aceto-iron-haematoxylin-chloral hydrate for chromosome staining. Stain Technology, 40: 161-164.

Womersley, H.B.S. \& Norris, R.E. (1971). The morphology and taxonomy of Australian Kallymeniaceae (Rhodophyta). Australian Journal of Botany, (Suppl. 2): 1-62.

Zuccarello, G.C. \& West, J.A. (2002). Phylogeography of the Bostrychia calliptera/B. pinnata complex (Rhodomelaceae, Rhodophyta) and divergence rates based on nuclear, mitochondrial and plastid DNA markers. Phycologia, 41: 49-60.

Zuccarello, G.C. \& Lokhorst, G.M. (2005). Molecular phylogeny of the genus Tribonema (Xanthophyceae) using $r b c \mathrm{~L}$ gene sequence data: monopoly of morphologically simple algal species. Phycologia, 44: 384-392. 